Sundari dan Fitriah, Tinjaun Hukum Terkait Tawaran Kredit Tanpa Agunan (KTA) Melalui Short Message Service (SMS), Halaman 64-76

\title{
TINJAUAN HUKUM TERKAIT TAWARAN KREDIT TANPA AGUNAN (KTA) MELALUI SHORT MESSAGE SER VICE (SMS)
}

\author{
Sundari $^{1}$ dan Fitriah ${ }^{2}$ \\ ${ }^{1}$ Universitas PGRI Palembang \\ E-mail: sundarinanung@gmail.com \\ ${ }^{2}$ Fakultas Hukum, Universitas Palembang \\ E-mail: fitriahsyahrial@gmail.com
}

\begin{abstract}
Related to Short Message Service (SMS) received from banks actually the government has provided protection for consumers of telecommunication service users, among others through the Regulation of the Minister of Communication and Informatics No. 5 of 2021 on the Implementation of Telecommunications (Permenkominfo 5/2021) which stipulates that telecommunication service providers must store telecommunication service customer data as long as telecommunication service customers actively subscribe to telecommunication services. This research aims to see what steps can be legally taken if you feel disturbed by the credit without collateral (KTA) offer given through short messages such as SMS. The research method used in this study is a normative method of law. First, telecommunication service providers are also required to keep the data and lor identity of customers secret unless otherwise specified under the law. Second, violations of these provisions by telecommunication service providers will be subject to administrative sanctions that can be in the form of written reprimands, the imposition of administrative fines, temporary suspension of attempted activities, termination of access, police force, revocation of services; and/or, revocation of the permit attempts.
\end{abstract}

Keywords: bank; credit; Short Message Service

Abstrak

Short Message Service (SMS) yang diterima dari bank dalam kebijakan pemerintah telah memberikan perlindungan bagi konsumen pengguna jasa telekomunikasi antara lain melalui Peraturan Menteri Komunikasi dan Informatika Nomor 5 Tahun 2021 tentang Penyelenggaraan Telekomunikasi (Permenkominfo 5/2021) yang mengatur bahwa penyelenggara jasa telekomunikasi wajib menyimpan data pelanggan jasa telekomunikasi selama pelanggan jasa telekomunikasi aktif berlangganan jasa telekomunikasi. Penelitian ini bertujuan untuk melihat langkah apa secara hukum yang dapat diambil jika merasa terganggu dengan tawaran Kredit Tanpa Anggunan (KTA) yang diberikan melalui pesan singkat seperti SMS. Metode penelitian yang dipakai pada penelitian ini adalah metode normatif hukum. Hasil penelitian ini adalah penyelenggara jasa telekomunikasi juga wajib merahasiakan data dan/atau identitas pelanggan kecuali ditentukan lain berdasarkan undang-undang. Pada pelanggaran terhadap ketentuan tersebut oleh penyelenggara jasa telekomunikasi akan dikenai sanksi administratif yang dapat berupa teguran tertulis, pengenaan denda administratif, penghentian sementara kegiatan berusaha, pemutusan akses, daya paksa polisional, pencabutan layanan; dan/atau, pencabutan perizinan berusaha.

Kata Kunci :.bank; kredit; SMS

\section{PENDAHULUAN}

Dalam era globalisasi seperti sekarang, kebutuhan akan mengakses suatu informasi adalah hal yang sangat penting dalam kehidupan sosial masyarakat. Informasi dibutuhkan 
Sundari dan Fitriah, Tinjaun Hukum Terkait Tawaran Kredit Tanpa Agunan (KTA) Melalui Short Message Service (SMS), Halaman 64-76

masyarakat untuk mengetahui segala macam berita yang terkait dengan perkembangan zaman. Salah satu cara untuk mengakses informasi, masyarakat menggunakan berbagai alat komunikasi. Alat komunikasi yang seringkali digunakan oleh masyarakat untuk mengakses berbagai macam informasi adalah telepon seluler.

Dengan pentingnya informasi tersebut maka diperlukan suatu pengaturan mengenai hal hal yang berkaitan dengan informasi elektronik. Untuk itu lahirlah Undang-Undang nomor 11 tahun 2008 tentang Informasi dan Transaksi Elektronik (selanjutnya disebut dengan UU ITE) sebagai wujud perlindungan hukum dan kepastian hukum bagi pengguna informasi dan transaksi elektronik.

Short Message Service (SMS) sebagai salah satu layanan operator yang sering digunakan masyarakat untuk berkomunikasi. SMS adalah suatu fasilitas untuk mengirim dan menerima suatu pesan singkat berupa teks melalui perangkat nirkabel, yaitu perangkat komunikasi telepon seluler, dalam hal ini perangkat nirkabel yang digunakan adalah telepon seluler. ${ }^{1}$

\footnotetext{
${ }^{1}$ Ilmu Komputer, "Pengertian SMS," 2021.
}

Salah satu kelebihan dari SMS adalah biaya yang murah. Selain itu SMS merupakan metode store dan forward sehingga keuntungan yang didapat adalah pada saat telepon seluler penerima tidak dapat dijangkau, dalam arti tidak aktif atau diluar service area, penerima tetap dapat menerima SMSnya apabila telepon selular tersebut sudah aktif kembali. Layanan SMS yang disediakan operator seluler selain berfungsi untuk berkomunikasi dengan orang lain, tetapi juga merupakan sarana yang sangat efektif untuk melakukan promosi, dan komunikasi karena akan langsung dibaca oleh pemilik telepon seluler. Dalam hal ini berarti SMS mempunyai multifunction. ${ }^{2}$

Biasanya operator seluler dalam hal ini bekerja sama dengan Perusahaan Penyedia Jasa layanan SMS Gateway untuk melakukan promosi. SMS Gateway adalah sebuah software atau aplikasi yang merubah proses mengolah SMS dari telepon selular ke Komputer PC/ Laptop, kemudian mengolah SMS seperti layaknya fitur di telepon selular, tetapi

\footnotetext{
2 Pradeep Kumar Roy, Jyoti Prakash Singh, dan Snehasish Banerjee, "Deep learning to filter SMS Spam," Future Generation Computer Systems $102 \quad$ (2020), https://doi.org/10.1016/j.future.2019.09.001.
} 
Sundari dan Fitriah, Tinjaun Hukum Terkait Tawaran Kredit Tanpa Agunan (KTA) Melalui Short Message Service (SMS), Halaman 64-76

ada perbedaan dari segi fitur, fungsi yang bisa dibuat berdasarkan kebutuhan bisnis. Istilah SMS Gateway dalam Permenkominfo Nomor 1 Tahun 2009 tentang pengaturan mengenai SMS Premium dan SMS Broadcast disebut dengan SMS broadcast.

SMS Gateway tersebut biasa digunakan oleh operator untuk menawarkan layanan kepada pengguna telepon seluler seperti : untuk mengaktifkan Ringtone, Wallpaper, bahkan tawaran untuk mengikuti kuis dan lain sebagainya.

Akhir-akhir ini banyak permasalahan yang timbul mengenai layanan SMS Gateway. Berikut ini ada kutipan mengenai permasalahan mengenai layanan SMS Gateway:

Badan Regulasi
Telekomunikasi Indonesia
(BRTI) dan Yayasan Lembaga
Konsumen Indonesia (YLKI)
menemukan fakta bahwa
sedikitnya $25 \quad$ juta data
pelanggan telekomunikasi di
Indonesia sudah bocor. Angka
ini mencapai 25 persen dari
sekitar 200 juta pelanggan
telekomunikasi yang terdaftar.
Fakta ini ditemukan dari
sebuah iklan di koran harian
nasional. Dalam iklan tersebut,
perusahaan penyedia layanan
SMS Gateway itu menyebutkan
'Menyediakan 25 Juta data
pelanggan seluler aktif, valid
dan legal, seluruh Indonesia

untuk SMS promo anda". Sayangnya hingga saat ini belum diketahui siapa pihak yang bertanggung jawab membocorkan data tersebut. Tidak heran jika kemudian banyak pengguna seluler yang mengeluh telah dibombardir SMS promo yang cukup mengganggu.

Penyediaan 25 juta SMS Gateway yang selama ini digunakan oleh operator seluler untuk mempromosikan fitur-fitur yang berguna bagi pelanggan operator seluler telah disalahgunakan oleh mereka yang tidak bertanggungjawab atas penyalahgunaan layanan SMS Gateway tersebut.

Selain permasalahan di atas, juga terdapat berbagai macam permasalahan yang timbul akibat adanya layanan SMS Gateway. Permasalahan tersebut yaitu mengenai adanya SMS Spam atau SMS sampah yang memenuhi ponsel pelanggan. Hal ini sangat meresahkan masyarakat. SMS spam ini ada yang berbentuk penipuan atau penawaran produk yang digunakan oleh perorangan atau kelompok.

Adanya SMS Spam atau sampah ini dilatarbelakangi adanya besarnya bonus sms lintas operator per hari. Berdasarkan catatan di lapangan terdapat dua nomor operator yang 
Sundari dan Fitriah, Tinjaun Hukum Terkait Tawaran Kredit Tanpa Agunan (KTA) Melalui Short Message Service (SMS), Halaman 64-76

sering digunakan untuk mengirimkan penawaran KTA. Kedua operator itu adalah Axis dan Tri. Axis memiliki penawaran gratis 10 ribu SMS per hari, sedangkan Tri 100 ribu SMS per hari. ${ }^{3}$

$$
\text { Adanya permasalahan- }
$$

permasalahan di atas, jika dikaitkan dengan peraturan perundang-undangan yang terkait dan berlaku di Indonesia baik mengenai peraturan mengenai Undang-Undang Nomor 36 Tahun 1999 tentang Telekomunikasi dan UndangUndang Nomor 11 Tahun 2008 tentang Informasi dan Transaksi Elektronik maupun peraturan-peraturan lainnya maka terdapat pelanggaranpelanggaran yang telah dilakukan. Pelanggaran tersebut yaitu mengenai SMS Spam yang merugikan konsumen. SMS Spam yang dikirimkan ke pelanggan tanpa izin si pemilik nomor dan si pengirim pun tidak mengantongi izin dari Badan Regulasi Telekomunikasi Indonesia (selanjutnya disebut BRTI) ini melanggar Permenkominfo No 01/2009 tentang Penyelenggaraan Jasa Pesan Premium dan Pengiriman Jasa Pesan Singkat.

Dalam kaitannya dengan adanya SMS Spam yang seringkali dikirimkan

3 Doni Ismanto, "SMS Spam Simalakama Strategi Pemasaran,” 2020. oleh pihak-pihak yang tidak bertanggung jawab terdapat berbagai macam keluhan dari sebagian besar masyarakat yang menerima SMS Spam tersebut. Para pengguna jasa operator seluler sering merasa terganggu dengan adanya SMS Spam baik yang menggunakan modus penipuan lewat permintaan pulsa, sms berhadiah, dan sebagainya. Tidak sebatas keluhan, para pengguna operator telepon seluler juga telah banyak menderita kerugian akibat adanya SMS Spam tersebut. Kerugian yang dialami oleh pengguna jasa operator berupa kerugian secara materiil maupun immateriil yaitu terganggunya kenyamanan dalam penggunaan jasa operator seluler.

\section{PEMBAHASAN}

\section{A. Karakteristik SMS Spam}

Dalam rangka mencapai untung yang setinggi-tingginya itu, para produsen/pelaku usaha harus bersaing antar pelaku usaha satu dengan pelaku usaha lainnya. Antara Pihak operator satu dengan yang lainnya bersaing untuk mencapai keuntungan yang sebesar- besarnya. Seringkali dalam persaingan yang dilakukan oleh pelaku usaha tersebut dapat menimbulkan kerugian bagi konsumen. Salah satunya 
Sundari dan Fitriah, Tinjaun Hukum Terkait Tawaran Kredit Tanpa Agunan (KTA) Melalui Short Message Service (SMS), Halaman 64-76

dengan cara mengeluarkan produk SMS broadcast.

Layanan SMS yang disediakan oleh operator mempunyai kelebihan, yaitu biayayang murah. Selain itu SMS merupakan metode store dan forward sehingga keuntungan yang didapat adalah pada saat telepon seluler penerima tidak dapat dijangkau, dalam arti tidak aktif atau diluar service area, penerima tetap dapat menerima SMSnya apabila telepon seluler tersebut sudah aktif kembali. ${ }^{4}$

Layanan SMS yang disediakan oleh operator saat ini mempunyai multifunction. Selain untuk menyediakan fasilitas bagi pengguna telepon seluler untuk mengakses berbagai macam informasi, tetapi juga sebagai sarana bagi pihak operator sendiri untuk melakukan SMS broadcast yang tujuannya untuk menawarkan berbagai macam promosi. SMS broadcast adalah SMS yang dikirim oleh operator yang ditujukan ke banyak tujuan. SMS broadcast tersebut berisi berbagai macam penawaran. Misalnya penawaran untuk mengikuti kuis, mengaktifkan ringtone, wallpaper sampai dengan penawaran yang bersifat pribadi seperti penawaran Kredit Tanpa Agunan (KTA).

SMS broadcast yang dikirim oleh pihak operator umumnya bersifat komersiil. Konsumen seringkali dirugikan dengan adanya SMS broadcast tersebut, karena SMS tersebut tidak dikehendaki oleh konsumen. Hal inilah yang akhir-akhir ini sering disebut dengan SMS Spam. SMS Spam adalah suatu penerimaan pesan singkat dari penyedia jasa layanan operator seluler, dimana isi dalam SMS tersebut tidak dikehendaki oleh pengguna jasa operator dan dilakukan secara terus menerus tanpa ijin pengguna jasa operator seluler.

Dikatakan Spam karena SMS tersebut isinya tidak dikehendaki oleh konsumen. Contohnya,kita sebagai pengguna seluler baik menggunakan operator apapun pasti pernah mendapatkan SMS dari operator bahkan sering, isi SMS tersebut terkadang bahkan hampir tidak penting bagi kita, seperti promosi iklan, kuiskuis, atau yang paling sering setiap kita selesai mengecek pulsa atau setelah menelpon rekan, akan ada kiriman SMS dari operator sekedar

\footnotetext{
${ }^{4}$ Roy, Singh, dan Banerjee, "Deep learning to filter SMS Spam.”
} 
Sundari dan Fitriah, Tinjaun Hukum Terkait Tawaran Kredit Tanpa Agunan (KTA) Melalui Short Message Service (SMS), Halaman 64-76

menawarkan iklan-iklan atau ring back tone. $^{5}$

SMS Spam yang dikirimkan kepada pelanggan tanpa izin si pemilik nomor dan si pengirim pun tidak mengantongi izin dari Badan Regulasi Telekomunikasi Indonesia (selanjutnya disebut BRTI) ini melanggar Permenkominfo No 01/2009 tentang Penyelenggaraan Jasa Pesan Premium dan Pengiriman Jasa Pesan Singkat.

Sebagai konsumen, maka pengguna jasa operator seluler mempunyai hak- hak yang dilindungi oleh undang-undang, khususnya Undang-Undang Nomor 8 Tahun 1999 tentang Perlindungan Konsumen. Hakhak konsumen tersebut diatur pada Pasal 4, salah satunya adalah hak atas kenyamanan, keamanan, dan keselamatan dalam mengkonsumsi barang dan/atau jasa. Dengan adanya hak tersebut, maka pengguna jasa operator selu ler mempunyai hak seperti yang telah disebutkan dalam Pasal 4 UU Perlindungan Konsumen.

SMS broadcast oleh pihak operator diduga melanggar salah satu ketentuan dalam Undang-Undang

5 Sarab M. Hameed, "Differential evolution detection models for SMS spam," International Journal of Electrical and Computer Engineering 11, no. 1 (2021), https://doi.org/10.11591/ijece.v11i1.pp596-601.
Nomor 36 Tahun 1999 tentang Telekomunikasi. Pada Pasal 21 Undang-Undang Telekomunikasi menyebutkan bahwa penyelenggara komunikasi dilarang melakukan kegiatan usaha penyelenggaraan telekomunikasi yang bertentangan dengan kepentingan umum, kesusilaan, keamanan dan ketertibanumum.

$$
\text { Adanya permasalahan- }
$$
permasalahan mengenai SMS Spam yang merugikan konsumen tersebut mengundang perhatian pemerintah untuk segera menyelesaikan permasalahan dengan langkah preventif maupun represif. Yang dimaksud dengan preventif adalah bersifat mencegah agar tidak terjadi. Jadi perlindungan hukum preventif adalah perlindungan hukum dalam peraturan perundang-undangan yang bersifat mencegah kerugian masyarakat, dalam hal ini adalah konsumen. Sedangkan yang dimaksud dengan represif adalah bersifat menekan dan mengekang. Jadi, yang dimaksud dengan perlindungan hukum represif adalah perlindungan hukum dalam bentuk upaya hukum yang dapat dilakukan konsumen yang merasa dirugikan, agar yang bersangkutan 
Sundari dan Fitriah, Tinjaun Hukum Terkait Tawaran Kredit Tanpa Agunan (KTA) Melalui Short Message Service (SMS), Halaman 64-76

mendapatkan kembali apa yang seharusnya menjadi haknya.

Mengenai SMS Spam, tidak ada ketentuan hukum di Indonesia yang mengatur secara khusus tentang keberlakuan SMS Spam. SMS Spam ini dapat dikaitkan dengan beberapa ketentuan-ketentuan yang relevan yang dapat dipergunakan sebagai bentuk perlindungan hukum terhadap adanya SMS Spam. Adapun ketentuanketentuan perundangan-undangan yang berkaitan dengan upaya perlindungan hukum konsumen atas adanya SMS Spam adalah Undang-Undang no.8 tahun 1999 tentang Perlindungan Konsumen, Peraturan Menteri Komunikasi dan Informasi Nomor 1 Tahun 2009 mengenai SMS premium danSMS broadcast.

\section{B. Tanggung Gugat Pelaku Usaha}

Pelaku usaha yang berperan selaku produsen memiliki tugas dan kewajiban untuk ikut serta menciptakan dan menjaga iklim usaha yang sehat untuk menunjang bagi pembangunan perekonomian nasional secara keseluruhan. Oleh sebab itu, produsen dibebankan tanggung gugat atas pelaksanaan tugas dan kewajiban itu, yaitu melalui penerapan norma- norma hukum, kepatutan dan menjunjung tinggi kebiasaan yang berlaku di kalangan dunia usaha. ${ }^{6}$

Kewajiban pelaku usaha untuk senantiasa beritikad baik dalam melakukan kegiatannya (Pasal 7 angka 1) berarti bahwa pelaku usaha terlibat dalam melakukan tanggung jawab untuk menciptakan iklim kondusif dalam berusaha demi menunjang pembangunan nasional. Banyak ketentuan di dalam Undang-Undang Perlindungan Konsumen ini yang bermaksud mengarahkan pelaku usaha untuk berperilaku sedemikian rupa dalam rangka menyukseskan pembangunan ekonomi nasional, khususnya di bidang usaha. Atas setiap pelanggaran yang dilakukan oleh produsen maka kepadanya dikenakan sanksi hukum, baik sanksi administratif maupun sanksi pidana. Pemberian sanksi ini penting mengingat bahwa menciptakan iklim usaha yang sehat membutuhkan keseriusan dan ketegasan. $^{7}$

Sesuai dengan ketentuan yang telah disebutkan dalam Pasal 7

6 Janus Sidabalok, Hukum Perlindungan Konsumen di Indonesia, 4 ed. (Jakarta: Citra Aditya Bakti, 2016).

${ }^{7}$ Nathanael Grady, "Tanggung Gugat Pelaku Usaha Otomotif Atas Kerugian Konsumen Akibat Cacat Desain," Jurist-Diction 3, no. 2 (2020), https://doi.org/10.20473/jd.v3i2.18205. 
Sundari dan Fitriah, Tinjaun Hukum Terkait Tawaran Kredit Tanpa Agunan (KTA) Melalui Short Message Service (SMS), Halaman 64-76

Undang-undang Perlindungan

Konsumen (selanjutnya disingkat

UUPK), maka pelaku usaha yang tidak memenuhi kewajibannya dapat dituntut secara hukum untuk mengganti segala kerugian yang timbul sehubungan dengan tidak dipenuhinya kewajiban itu. Pelaku usaha dalam hal ini penyedia jasa layanan operator seluler mempunyai kewajiban memberikan kompensasi atau ganti rugi atas kerugian konsumen akibat adanya SMS broadcast yang melanggar hak konsumen yaitu hak atas kenyamanan.

Menurut pasal 19 ayat (1) UUPK disebutkan bahwa pelaku usaha bertanggungjawab memberikan ganti rugi atas kerusakan, pencemaran, dan/atau kerugian konsumen akibat mengonsumsi barang dan/atau jasa yang dihasilkan atau diperdagangkan. Sistem tanggung gugat yang terdapat pada UUPK secara garis besar merupakan sistem tanggung gugat kesalahan, dimana diperlukan adanya pembuktian unsur kesalahan dan menggunakan asas pembalikan beban pembuktian. Tanggung gugat kesalahan dengan pembalikan beban pembuktian yang dianut UUPK, mengandung makna bahwa yang berkewajiabn untuk membuktikan ada tidaknya unsur kesalahan adalah pihak pelaku usaha. Bilamana pelaku usaha tidak dapat membuktikan bahwa ia tidak bersalah atau ia telah terbukti melakukan kesalahan, maka pelaku usaha berkewajiban untuk memberukan ganti rugi pada konsumen. $^{8}$

Sistem tanggung gugat kesalahan dengan pembalikan beban pembuktian ini secara eksplisit dirumuskan dalam Pasal 28 UUPK “ Pembuktian terhadap ada tidaknya unsur kesalahan dalam gugatan ganti rugi sebagaimana dimaksud dalam pasal 19, pasal 22, pasal 23 merupakan beban dan tanggung jawab pelaku usaha." Tanggung gugat kesalahan dengan pembalikan beban pembuktian ini merupakan salah satu bentuk tanggung gugat yang dipertajam, dengan sistem ini posisi konsumen yang dirugikan akan diperkuat dengan tidak mengabikan unsur-unsur tanggung gugat kesalahan.

\section{Penawaran Kredit Tanpa Agunan (KTA) Melalui SMS}

\footnotetext{
${ }^{8}$ Ari Purwadi, "Tanggung Gugat Pelaku Usaha Periklanan Ditinjau Dari Perlindungan Konsumen," NORMA 1, no. 1 (2004), https://doi.org/10.30742/nlj.v1i1.1046.
} 
Sundari dan Fitriah, Tinjaun Hukum Terkait Tawaran Kredit Tanpa Agunan (KTA) Melalui Short Message Service (SMS), Halaman 64-76

Pengaturan terhadap penawan produk Kredit Tanpa Anggunan (KTA) oleh Pelaku Usaha Jasa Keuangan (PUJK), yang dalam hal ini adalah bank, kita dapat merujuk pada Peraturan Otoritas Jasa Keuangan Nomor 1/POJK.07/2013 Tahun 2013 tentang Perlindungan Konsumen Sektor Jasa Keuangan (POJK 1/2013) dan Surat Edaran Otoritas Jasa Keuangan Nomor 12/SEOJK.07/2014 Tahun 2014 tentang Penyampaian Informasi dalam Rangka Pemasaran Produk dan/atau Layanan Jasa Keuangan (SEOJK 12/2014).

Pada dasarnya, PUJK dilarang melakukan penawaran produk dan/atau layanan kepada konsumen dan/atau masyarakat melalui sarana komunikasi pribadi tanpa persetujuan konsumen. ${ }^{9}$ Yang dimaksud dengan "sarana komunikasi pribadi" dalam hal ini adalah sarana komunikasi yang bersifat personal misalnya antara lain email, short message system, dan voicemail. ${ }^{10}$

Sedangkan yang dimaksud dengan PUJK adalah Bank Umum,

\footnotetext{
9 Peraturan Otoritas Jasa Keuangan Nomor 1/POJK.07/2013 Tahun 2013 tentang Perlindungan Konsumen Sektor Jasa Keuangan, “.” (n.d.), a. Pasal19.

10 Peraturan Otoritas Jasa Keuangan Nomor 1/POJK.07/2013 Tahun 2013 tentang Perlindungan Konsumen Sektor Jasa Keuangan, .
}

Bank Perkreditan Rakyat, Perusahaan Efek, Penasihat Investasi, Bank Kustodian, Dana Pensiun, Perusahaan Asuransi, Perusahaan Reasuransi, Lembaga Pembiayaan, Perusahaan Gadai, dan Perusahaan Penjaminan, baik yang melaksanakan kegiatan usahanya secara konvensional maupun secara syariah. ${ }^{11}$

Ketentuan lebih lanjut mengenai hal ini dapat dilihat dalam SEOJK 12/2014 yang memang tidak spesifik membahas mengenai penawaran produk keuangan seperti KTA melalui Short Message Service (SMS), tetapi memuat beberapa prosedur penawaran produk dan layanan jasa keuangan oleh PUJK melalui berbagai media, termasuk SMS.

\section{Berdasarkan SEOJK 12/2014,} PUJK, dalam hal penyampaian informasi melalui sarana komunikasi pribadi (telepon, text message, email, dan yang dapat dipersamakan dengan itu) atau kunjungan langsung harus memenuhi hal-hal sebagai berikut: ${ }^{12}$

\footnotetext{
11 Peraturan Otoritas Jasa Keuangan Nomor 1/POJK.07/2013 Tahun 2013 tentang Perlindungan Konsumen Sektor Jasa Keuangan. 12 Surat Edaran Otoritas Jasa Keuangan Nomor 12/SEOJK.07/2014 Tahun 2014 tentang Penyampaian Informasi Dalam Rangka Pemasaran Produk dan/atau Layanan Jasa Keuangan, “.”(n.d.), a. Bagian V Angka 4.
} 
Sundari dan Fitriah, Tinjaun Hukum Terkait Tawaran Kredit Tanpa Agunan (KTA) Melalui Short Message Service (SMS), Halaman 64-76

a. Komunikasi hanya dapat dilakukan pada hari Senin sampai dengan Sabtu di luar hari libur nasional dari pukul 08.00 - 18.00 waktu setempat, kecuali atas persetujuan atau permintaan calon konsumen atau konsumen;

b. Menginformasikan nama PUJK dan menjelaskan maksud dan tujuan terlebih dahulu sebelum menawarkan produk dan/atau layanan PUJK; dan

c. Dalam hal PUJK menggunakan sarana komunikasi pribadi berupa telepon:

1. PUJK wajib menyediakan dan menggunakan alat rekam suara;

2. Jika diperlukan sebagai alat bukti adanya perbuatan hukum yang dilakukan oleh konsumen dan PUJK di pengadilan dan/atau diperlukan oleh bidang pengawas maka wajib disajikan dalam hasil cetakan dan/atau surat yang ditandatangani oleh konsumen; dan

3. Alat rekam suara yang menyampaikan persetujuan konsumen yang disajikan dalam hasil cetakan dapat dipersamakan dengan pernyataan persetujuan tertulis yang ditandatangani oleh konsumen.

Jadi, pada dasarnya PUJK memang dilarang melakukan penawaran produk dan/atau layanan kepada konsumen dan/atau masyarakat melalui sarana komunikasi pribadi, kecuali telah ada persetujuan konsumen. Jika seorang dari pihak
PUJK menawarkan produk atau jasa keuangan dengan cara menyampaikan informasi melalui media seperti SMS, email bahkan telepon, maka ia harus memenuhi ketentuan yang telah ditetapkan dalam SEOJK 12/2014, seperti, antara lain, etika waktu yang diperbolehkan untuk berkomunikasi hanya dapat dilakukan pada hari Senin sampai dengan Sabtu di luar hari libur nasional dari pukul $08.00-18.00$ waktu setempat, kecuali atas persetujuan atau permintaan calon konsumen atau konsumen.

Selain itu, apabila PUJK menggunakan pihak ketiga dalam hal memasarkan produk dan/atau layanannya terdapat juga aturannya sebagai berikut: ${ }^{13}$

1. PUJK wajib bertanggung jawab kepada konsumen atas tindakan yang dilakukan oleh pihak ketiga yang bertindak untuk kepentingan PUJK, misalnya dalam hal memasarkan produk dan/atau layanan PUJK.

2. Pihak ketiga yang melakukan pemasaran wajib menyampaikan semua informasi dan data yang termuat dalam ringkasan informasi produk dan/atau layanan sebagaimana dimaksud pada bab VI angka 4 SEOJK 12/2014.

\footnotetext{
${ }^{13}$ Surat Edaran Otoritas Jasa Keuangan Nomor 12/SEOJK.07/2014 Tahun 2014 tentang Penyampaian Informasi Dalam Rangka Pemasaran Produk dan/atau Layanan Jasa Keuangan, .
} 
Sundari dan Fitriah, Tinjaun Hukum Terkait Tawaran Kredit Tanpa Agunan (KTA) Melalui Short Message Service (SMS), Halaman 64-76

3. Pihak ketiga yang melakukan pemasaran wajib menyampaikan informasi dan data secara sederhana, sesuai dengan fakta, tidak mengandung unsur kebohongan/penipuan, dapat dimengerti oleh konsumen dan tidak menimbulkan multitafsir.

\section{Sanksi dan Langkah Hukum}

Berdasarkan POJK 1/2013, PUJK dan/atau pihak yang melanggar ketentuan dalam POJK 1/2013 ini dikenakan sanksi administratif, antara lain berupa: ${ }^{14}$

a. Peringatan tertulis;

b. Denda yaitu kewajiban untuk membayar sejumlah uang tertentu;

c. Pembatasan kegiatan usaha;

d. Pembekuan kegiatan usaha; dan

e. Pencabutan izin kegiatan usaha.

Selain itu, jika dalam menyampaikan informasi seputar produk dan/atau layanan jasa keuangan ini PUJK melanggar ketentuan waktu komunikasi yang ditentukan yaitu dilakukan tanpa

persetujuan/permintaan

konsumen/calon konsumen, atau ketentuan waktu pada hari Senin sampai dengan Sabtu di luar hari libur nasional dari pukul $08.00-18.00$ waktu setempat tanpa ada persetujuan/permintaan calon

14 Peraturan Otoritas Jasa Keuangan Nomor 1/POJK.07/2013 Tahun 2013 tentang Perlindungan Konsumen Sektor Jasa Keuangan, . konsumen/konsumen, Anda dapat menyampaikan pengaduan tentang hal ini kepada $\mathrm{OJK}^{15}$ dengan dilengkapi dokumen dan informasi minimal sebagai berikut: ${ }^{16}$

a. identitas konsumen dan/atau masyarakat;

b. alamat surat menyurat, nomor telepon yang dapat dihubungi atau alamat surat elektronik (email); dan

c. materi atau deskripsi pengaduan berindikasi pelanggaran.

\section{E. Hak Konsumen Jasa}

\section{Telekomunikasi}

Berkaitan SMS yang diterima dari bank sebenarnya pemerintah telah memberikan perlindungan bagi konsumen pengguna jasa telekomunikasi antara lain melalui Peraturan Menteri Komunikasi dan Informatika Nomor 5 Tahun 2021 tentang Penyelenggaraan

Telekomunikasi

(Permenkominfo 5/2021) yang mengatur bahwa penyelenggara jasa telekomunikasi wajib menyimpan data pelanggan jasa

\footnotetext{
15 Peraturan Otoritas Jasa Keuangan Nomor 31/POJK.07/2020 Tahun 2020 tentang Penyelenggaraan Layanan Konsumen dan Masyarakat di Sektor Jasa Keuangan oleh Otoritas Jasa Keuangan, “.” (n.d.), a. Pasal 19 Ayat (1).

16 Peraturan Otoritas Jasa Keuangan Nomor 31/POJK.07/2020 Tahun 2020 tentang Penyelenggaraan Layanan Konsumen dan Masyarakat di Sektor Jasa Keuangan oleh Otoritas Jasa Keuangan, .
} 
Sundari dan Fitriah, Tinjaun Hukum Terkait Tawaran Kredit Tanpa Agunan (KTA) Melalui Short Message Service (SMS), Halaman 64-76

telekomunikasi selama pelanggan jasa telekomunikasi aktif berlangganan jasa telekomunikasi. $17 \quad$ Kemudian, penyelenggara jasa telekomunikasi juga wajib merahasiakan data dan/atau identitas pelanggan kecuali ditentukan lain berdasarkan undang-undang. ${ }^{18}$

Itu artinya jika merasa tidak pernah memberikan nomor telepon Anda pada pihak PUJK (bank) dan apabila pihak bank memperoleh nomor telepon Anda dari penyedia jasa telekomunikasi (operator) maka tentu hal ini telah menyalahi aturan sebagaimana tercantum dalam Permenkominfo 5/2021.

Pelanggaran terhadap ketentuan tersebut oleh penyelenggara jasa telekomunikasi akan dikenai sanksi administratif yang dapat berupa: 19

a. teguran tertulis;

b. pengenaan denda administratif;

c. penghentian sementara kegiatan berusaha;

d. pemutusan akses;

e. daya paksa polisional;

17 Peraturan Menteri Komunikasi dan Informatika Nomor 5 Tahun 2021 tentang Penyelenggaraan Telekomunikasi, "." (n.d.), a . Pasal168 ayat (1).

18 Peraturan Menteri Komunikasi dan Informatika Nomor 5 Tahun 2021 tentang Penyelenggara an Telekomunikasi,

19 Peraturan Menteri Komunikasi dan Informatika Nomor 5 Tahun 2021 tentang Penyelenggara an Telekomunikasi. f. pencabutan layanan; dan/atau

g. pencabutan perizinan berusaha.

\section{KESIMPULAN}

Merujuk pada hasil pembahasan yang ada , maka dapat ditarik kesimpulan sebagai berikut:

1. Berkaitan SMS yang diterima dari bank sebenarnya pemerintah telah memberikan perlindungan bagi konsumen pengguna jasa telekomunikasi antara lain melalui Peraturan Menteri Komunikasi dan Informatika Nomor 5 Tahun 2021 tentang Penyelenggaraan Telekomunikasi (Permenkominfo 5/2021).

2. Penyelenggara jasa telekomunikasi juga wajib merahasiakan data dan/atau identitas pelanggan kecuali ditentukan lain berdasarkan undangund ang.

3. Pelanggaran terhadap ketentuan tersebut oleh penyelenggara jasa telekomunikasi akan dikenai sanksi administratif yang dapat berupa teguran tertulis, pengenaan denda administratif, penghentian sementara kegiatan berusaha, pemutusan akses, daya paksa polisional, pencabutan layanan; 
Sundari dan Fitriah, Tinjaun Hukum Terkait Tawaran Kredit Tanpa Agunan (KTA) Melalui Short Message Service (SMS), Halaman 64-76

dan/atau, pencabutan perizinan berusaha.

\section{DAFTAR PUSTAKA}

Ari Purwadi, "Tanggung Gugat Pelaku Usaha Periklanan Ditinjau Dari Perlindungan Konsumen," NORMA 1, no. 1 (2004), https://doi.org/10.30742/nlj.v1i1. 1046.

Doni Ismanto, "SMS Spam Simalakama Strategi Pemasaran," 2020.

Ilmu Komputer, "Pengertian SMS," 2021.

Janus Sidabalok, Hukum Perlindungan

Konsumen di Indonesia, 4 ed. (Jakarta: Citra Aditya Bakti, 2016).

Nathanael Grady, "Tanggung Gugat Pelaku Usaha Otomotif Atas Kerugian Konsumen Akibat Cacat Desain," Jurist-Diction 3, no. 2 (2020), https://doi.org/10.20473/jd.v3i2.1 8205.

Peraturan Menteri Komunikasi dan Informatika Nomor 5 Tahun 2021 tentang Penyelenggaraan Telekomunikasi.

Peraturan Otoritas Jasa Keuangan Nomor 1/POJK.07/2013 Tahun 2013 tentang Perlindungan Konsumen Sektor Jasa Keuangan. Peraturan Otoritas Jasa Keuangan Nomor 31/POJK.07/2020 Tahun 2020 tentang Penyelenggaraan Layanan Konsumen dan Masyarakat di Sektor Jasa
Keuangan oleh Otoritas Jasa Keuangan.

Pradeep Kumar Roy, Jyoti Prakash Singh, dan Snehasish Banerjee, "Deep learning to filter SMS Spam," Future Generation Computer Systems 102 (2020), https://doi.org/10.1016/j.future.2 019.09.001.

Roy, Singh, dan Banerjee, "Deep learning to filter SMS Spam."

Sarab M. Hameed, "Differential evolution detection models for SMS spam," International Journal of Electrical and Computer Engineering 11, no. 1 (2021), https://doi.org/10.11591/ijece.v1 1i1.pp596-601.

Surat Edaran Otoritas Jasa Keuangan Nomor 12/SEOJK.07/2014 Tahun $2014 \quad$ tentang Penyampaian Informasi Dalam Rangka Pemasaran Produk dan/atau Layanan Jasa Keuangan. 